\title{
Letter from the Editor-in-Chief: Reverse knowledge transfers, culture clashes and going international
}

\section{Lorraine Eden}

Journal of International Business Studies (2009) 40, 177-180.

doi: $10.1057 / j i b s .2008 .98$
Issue 40.2 consists of nine articles, all accepted for publication by former JIBS Editor-in-Chief Arie Y. Lewin. The articles are grouped around several important themes in international business (IB) research.

\section{Reverse Knowledge Transfers}

Multinational enterprises (MNEs) are, sina qua non, the world's most efficient and prolific producers of knowledge (process and product technology, management skills, intangible assets). Once produced, exploiting that knowledge is a primary motivation for foreign direct investment (FDI) as MNEs go abroad to earn rents on their knowledge-based assets created at home. Through the process of FDI, MNEs transfer knowledge and capital to their foreign affiliates in host countries.

This picture - MNEs as creators, exploiters and transferrors of knowledge - suggests a one-way transfer from the parent firm in the home country out to foreign affiliates in host countries. However, this picture has been getting old for some time and is now close to obsolete. Most MNEs are now horizontally and vertically integrated networks where knowledge flows in all directions within the network, including the parent firm. MNEs from emerging economies in Asia and Latin America now engage in "springboard FDI", going abroad to explore for knowledge and bringing it home. Metanationals - MNEs "born in the wrong place" - depend on knowledge learned abroad that is transferred back to the parent firm.

As a result, knowledge-seeking FDI now commands as much attention from scholars as knowledge-exploiting FDI did in the 1980s. IB scholars have increasingly focused their attention on inbound or reverse knowledge transfers - antecedents, processes and consequences. However, research on knowledge transfers within and by MNEs faces a high hurdle: how does one measure the direction, size and impact of knowledge transfers? The most popular approach has been to track patent data citations. Patent data have provided a relatively easy "trail" for mapping intrafirm and interfirm knowledge flows, both planned transfers and spillovers. Most scholars in this area have used patent data, building on the seminal works of Patel and Pavitt (1991) and 
Almeida (1996). The second, more detailed and time-consuming appoach - mapping knowledge flows within a single MNE - was developed in Gupta and Govindarajan (2000), using surveys of top managers of foreign affiliates who were asked to rank seven types of knowledge inflows and outflows, with the MNE parent firm and sister affiliates, on a 7-point Likert scale. A third and newest approach is to examine knowledge transfers through expatriates.

MNEs are organizations made up of people. Organizational knowledge can therefore come from individuals producing knowledge that is transferred from the individual to the organizational level. This suggests that the individual can be a useful lens on knowledge transfers within organizations. More specifically, by focusing on expatriates who are sent on overseas assignments and then return to their original work unit, researchers have a third path to understanding how firms bring knowledge home and diffuse it throughout the MNE network.

This issue of JIBS contains two articles about the reverse knowledge transfer process as evidenced through expatriates returning back to headquarters after a foreign assignment. The first article, "Repatriating knowledge: Variables influencing the 'transfer' process", by Oddou, Osland and Blakeney, is a theoretical paper, developing propositions about effective knowledge transfers. The authors argue that MNEs seldom actively "harvest" knowledge developed during expat assignments, seeing the process as primarily one of transfering knowledge from the work unit (normally the parent firm) to foreign affiliates. Little theoretical or empirical work has been done on either the variables affecting, or the process of, repatriate knowledge transfers. Oddou and co-authors hypothesize that repatriate knowledge transfers should depend on characteristics of the individual (his/her expertise, social networks, position power, similarity of assignments, career salience and commitment), characteristics of the work unit (orientation to learning, absorptive capacity, knowledge criticality, global mindset) and the perceived trust between repatriates and their work unit. In other words, knowledge transfers depend on the individual's ability and willingness to transfer his/her learning experiences and the organization's ability and willingness to receive these transfers.

The Oddou et al. article is followed by "Managing the learning and transfer of global management competence: Antecedents and outcomes of Japanese repatriation effectiveness", by Furuya, Stevens, Bird, Oddou and Mendenhall, which examines the factors affecting both expatriate learning and expat knowledge transfers after repatriation. Their results draw from surveys of 305 repatriated employees of five Japanese MNEs. The authors argue that higher levels of organizational support, intercultural personality characteristics and expatriate self-adjustment should positively affect global management competency learning and transfers. Moreover, higher knowledge repatriation should positively affect job motivation and general work performance. In other words, ability and willingness plus organizational support - facilitate reverse knowledge transfers. The authors conclude that, if the purpose of sending managers overseas is to develop global competencies and business knowledge, a critical next step is for MNEs to set up organizational support mechanisms that facilitate bringing the knowledge back home - from the repatriates to the parental unit and then diffused throughout the MNE network.

\section{Culture Clashes}

The adage that "men are from Mars; women are from Venus" focuses on culture clashes arising from gender differences. In "Mars-Venus marriages: Culture and cross-border M\&A", Chakrabarti, Gupta-Mukherjee and Jayaraman argue that this general wisdom is wrong when applied to cross-border acquisitions. Cultural clashes do not necessarily cause M\&As to perform poorly; if the potential alliance synergies are high, these dominate and lead to long-run positive performance. In their study of 1157 acquisitions involving 43 acquirer and 65 target countries over 1991-2004, the authors find that while national cultural distance has a negative impact on short-term announcement returns of cross-border acquisitions, the long-run buy-and-hold abnormal returns (BHARs) are higher when national cultural distance (using Hofstede indices) between the acquirer and target firms is large. Thus, the old adage is wrong - at least for Mars-Venus marriages in cross-border acquisitions.

Our second article on culture, by Gould and Grein, "Think glocally, act glocally: A culturecentric comment on Leung, Bhagat, Buchan, Erez and Gibson (2005)", argues that it is important for IB scholars to move from a focus on national culture to a more globalized, flatter concept of culture. The authors make a persuasive argument that focusing solely on national culture ignores 
cultural phenomena such as networks and communities, and other levels besides the national level (e.g., micro, meta, global). The authors conclude that cultural patterns and processes should have a "more central place in IB research".

\section{Going International}

Several articles in this issue address questions of going international, focusing on the birth and growth of IB forms. Starting with the birth of MNEs, the growing internationalization of small and medium enterprises (SMEs) raises issues for traditional theories of why firms go abroad. In these explanations (e.g., the OLI paradigm, the resourcebased view) strong firm-specific advantages are needed to overcome the costs of doing business abroad, including the liability of foreignness. SMEs, however, suffer from liabilities of newness and smallness, lacking the firm-specific resources (financial, tangible and intangible) needed to compete in foreign markets. In "International business competence and the contemporary firm", Knight and Kim provide an alternative explanation for this conundrum. They argue that successful internationalizing SMEs have developed a different kind of resource - an international business competence (IBC) - that explains their success at internationalization. This IBC is based on intangible capabilities in four areas: international orientation, international marketing skills, international innovativeness and international market orientation. These four skills emerged from exploratory case studies with interviews of senior managers at 16 internationalized SMEs, and a follow-up survey of 354 managers and CEOs of successful SMEs.

Cross-border B2B (business-to-business) services are a new and rapidly expanding form of IB. La, Patterson and Styles, in "Client perceived performance and value in professional B2B services: An international perspective", use insights from the resource-based view to explore how an international B2B service provider's firm-specific resources affect its performance and value as seen by its foreign clients. The authors hypothesize that the relationship is influenced by three moderators (country of origin, international experience and client buying experience). The hypotheses find support from a survey of 218 client firms from Malaysia and Thailand that purchased B2B professional services.

Turning now to the birth and growth of crossborder alliances, Yeniyurt, Townsend, Cavusgil and
Ghauri, in "Mimetic and experiential effects in international marketing alliance formations of US pharmaceuticals firms: An event history analysis", examine the impacts of experiential learning and mimetic behavior on the formation of non-equity marketing alliances. Looking at 793 alliances by 317 US pharmaceutical firms between 1984 and 2003 , the authors find support for a co-evolutionary framework where alliances generate more alliances as firms mimic their competitors. Moreover, cultural distance experience is positively related to a firm's propensity to engage in more cross-border alliances. Eventually however, the benefits of alliance formation are offset by coordination costs and congestion effects, and alliance formation slows.

When firms internationalize, a critically important issue for growth and survival of the foreign affiliate is the choice of entry mode. One article in this issue focuses on this topic. Musteen, Datta and Hermann, in "Ownership structure and CEO compensation: Implications for the choice of foreign market entry modes", find that the selection of full-control equity modes for foreign affiliates is positively related to high equity ownership by institutional shareholders and inside directors, and to CEO pay tied to long-term performance.

A second issue MNEs face when they internationalize is how deeply embedded the foreign affiliate should become in the host country. Greater embeddedness through developing relational ties with host country insiders reduces liability of foreignness, but is this uniformly a good thing? In "Competitive position, managerial ties, and profitability of foreign firms in China: An interactive perspective", Li, Zhou and Shao argue that developing relational ties is not necessarily beneficial to foreign firms in emerging economies. When foreign firms follow a differentiation strategy in an emerging economy such as China, the authors find that political ties actually weaken, while business ties strengthen, the benefits of a differentiation strategy on affiliate performance. This finding - that host-country political ties weaken profitability of foreign affiliates - accords with previous research on the negative performance impacts of shelter strategies (Rugman \& Verbeke, 1990), but contradicts other research on the beneficial effects of cooperative MNE-state relations (Luo, 2001), suggesting that more research is needed to sort out these conflicting results. 


\section{REFERENCES}

Almeida, P. 1996. Knowledge sourcing by foreign multinationals: Patent citation analysis in the US semiconductor industry. Strategic Management Journal, 17(Winter Special Issue): 155-165.

Gupta, A. K., \& Govindarajan, V. 2000. Knowledge flows within multinational corporations. Strategic Management Journal, 21(4): 473-496.

Luo, Y. 2001. Toward a cooperative view of MNC-host government relations: Building blocks and performance implications. Journal of International Business Studies, 32(3): 401-419.

Patel, P., \& Pavitt, K. 1991. Large firms in the production of the world's technology - An important case of nonglobalization. Journal of International Business Studies, 22(1): $1-21$.

Rugman, A. M., \& Verbeke, A. 1990. Global corporate strategy and trade policy. London: Routledge. 